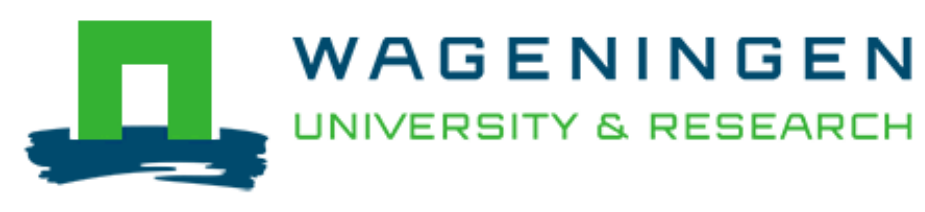

The effect of plant-based diet and suboptimal environmental conditions on digestive function and diet-induced enteropathy in rainbow trout (Oncorhynchus mykiss)

\author{
Mosberian-Tanha, P., Schrama, J. W., Landsverk, T., Mydland, L. T., \& \\ $\varnothing$ verland, $M$.
}

This article is made publically available in the institutional repository of Wageningen University and Research, under article $25 \mathrm{fa}$ of the Dutch Copyright Act, also known as the Amendment Taverne.

Article 25 fa states that the author of a short scientific work funded either wholly or partially by Dutch public funds is entitled to make that work publicly available for no consideration following a reasonable period of time after the work was first published, provided that clear reference is made to the source of the first publication of the work.

For questions regarding the public availability of this article, please contact openscience.library@wur.nl.

Please cite this publication as follows:

Mosberian-Tanha, P., Schrama, J. W., Landsverk, T., Mydland, L. T., \& Øverland, M. (2018). The effect of plant-based diet and suboptimal environmental conditions on digestive function and diet-induced enteropathy in rainbow trout (Oncorhynchus mykiss). Aquaculture Nutrition, 24(1), 112-122. https://doi.org/10.1111/anu.12539 


\title{
The effect of plant-based diet and suboptimal environmental conditions on digestive function and diet-induced enteropathy in rainbow trout (Oncorhynchus mykiss)
}

\author{
P. Mosberian-Tanha ${ }^{1}$ \\ J.W. Schrama ${ }^{2}$ \\ T. Landsverk ${ }^{3}$ \\ L.T. Mydland ${ }^{1}$ \\ M. Øverland ${ }^{1}$
}

\author{
${ }^{1}$ Department of Animal and Aquacultural \\ Sciences, Norwegian University of Life \\ Sciences, Ås, Norway \\ ${ }^{2}$ Aquaculture and Fisheries \\ Group, Wageningen Institute of Animal \\ Sciences, Wageningen, The Netherlands \\ ${ }^{3}$ Department of Basic Sciences and \\ Aquatic Medicine, School of Veterinary \\ Medicine, Norwegian University of Life \\ Sciences, Oslo, Norway \\ Correspondence \\ Margareth Øverland, Department of Animal \\ and Aquacultural Sciences, Norwegian \\ University of Life Sciences, Ås, Norway. \\ Email: margareth.overland@nmbu.no

\section{Funding information} \\ AQUAEXCEL (Aquaculture Infrastructures for \\ Excellence in European Fish Research), Grant/ \\ Award Number: 0071/05/13/30/A; Foods of \\ Norway, Grant/Award Number: 237841/030
}

\begin{abstract}
This experiment investigated intestinal enteropathy and digestive function of rainbow trout challenged with soybean meal-based $\operatorname{diet}(\mathrm{SBM})$ at optimal or suboptimal environments created by normal or reduced water flow, respectively. Oxygen level remained above $7 \mathrm{mg} \mathrm{L}^{-1}$ for optimal environment and between 4 and $5 \mathrm{mg} \mathrm{L}^{-1}$ for suboptimal environment. Triplicate groups of fish (mean body weight $74 \mathrm{~g}$ ) were fed fishmeal-based diet (FM) or SBM at optimal environment in period 1 (28 days). In period 2 ( 42 days), fish were subjected to a change from FM to SBM or remained on the same diet as used in period 1 . The fish were also exposed to change from optimal to suboptimal environment or remained under optimal conditions. The fish subjected to change from FM to SBM, regardless of their environment, showed similar degree of enteropathy from day 14. Lipid and starch digestibility was lower in SBM-fed fish at suboptimal environment compared to fish fed the same diet at optimal environment. Crude protein digestibility, however, was highest in SBM-fed fish at suboptimal environment throughout period 2. In conclusion, in SBM-fed rainbow trout, exposure to suboptimal environment did not change the degree of enteropathy; however, lipid and starch digestibility were further reduced.
\end{abstract}

\section{KEYWORDS}

apparent digestibility coefficients, digestive function, enteritis, hypoxia, rainbow trout, soybean meal

\section{1 | INTRODUCTION}

The use of plant ingredients in salmonid feeds to improve sustainability of aquaculture may lead to challenges including impaired digestive function, reduced growth and increased risk of developing gastrointestinal disorders such as soybean meal-induced enteritis (SBMIE). The negative effects of plant ingredients are attributed to the presence of non-starch polysaccharides (NSP) and antinutritional factors (ANF). SBM has been used as a model to study the effect of plant ingredients on gut health and function of salmonids (Krogdahl, Bakke-Mckellep, \& Baeverfjord, 2003; Mosberian-Tanha et al., 2016; Romarheim et al., 2008; Urán, Aydin, Schrama, Verreth, \& Rombout, 2008). The inclusion of SBM has shown to adversely affect the apparent digestibility coefficients (ADC) of nutrients and energy (Opstvedt et al., 2003; Romarheim et al., 2006). Furthermore, it has been shown that SBM can reduce activity of digestive enzymes in the distal intestine (DI) of Atlantic salmon (Salmo salar) (Chikwati et al., 2013; Krogdahl et al., 2003). The reduced activity of digestive function may partly be due to the morphological changes caused by SBMIE. Although DI is not the main site for macronutrient absorption, some important components such as taurine and bile acids have been shown to be re-absorbed in the DI (Nordrum, Krogdahl, Røsjø, Olli, \& Holm, 2000) with possible implications for the absorption of lipid in the proximal parts of the intestine. Morphological changes associated with SBMIE may disturb the capacity of digestion and re-absorption of nutritionally important substances in the DI and thus contribute to the lower ADC 
of nutrients. ADC of lipid in particular have shown to be reduced in Atlantic salmon fed SBM (Krogdahl et al., 2003; Romarheim et al., 2006). Changes in digestive function appears to be a more sensitive parameter than changes in the gut morphology as observed in Atlantic cod (Gadus morhua), where feeding SBM reduced lipid digestibility (Førde-Skjærvik, Refstie, Aslaksen, \& Skrede, 2006) in the absence of SBMIE (Refstie et al., 2006).

Aquaculture is also facing challenges from the environment. Suboptimal environmental conditions are partly caused by seasonal changes in water temperature and consequently dissolved oxygen (DO) (Oppedal, Dempster, \& Stien, 2011) or on a long-term basis by global warming leading to alterations in water quality parameters such as increased temperature and $\mathrm{CO}_{2}$ level (Lough \& Hobday, 2011). However, the adverse conditions may also be induced by some production procedures such as reduced water flow/exchange rate in intensive fish farming (Ellis et al., 2002). Water DO level is one of the important environmental factors affected by change in temperature or water flow rate. Low water DO level may induce environmental hypoxia with physiological consequences in fish (Wu, 2002). Adverse effect of low water DO on feed intake and growth has been reported in Nile tilapia (Oreochromis niloticus) (Tran-Duy, Van Dam, \& Schrama, 2012) and rainbow trout (Glencross, 2009). Exposure of the fish to low DO level resulted in impaired intestinal barrier function and also induced morphological changes in the distal intestine in Atlantic salmon (Sundh et al., 2010). Reduced water flow rate is not only associated with stress or low water DO but also increased accumulation of fish excretions such as ammonia in the ambient water (Ellis et al., 2002). High ambient ammonia concentration has been reported to reduce feed intake and increase mortality in juvenile lake trout (Salvelinus namayeush) (Beamish \& Tandler, 1990), and under chronic exposure, it also causes gill damage and hyperplasia (Meade, 1985). In contrary, in another experiment, chronic exposure to sublethal levels of ammonia did not change feed intake in Atlantic salmon kept at $12^{\circ} \mathrm{C}$ (Kolarevic et al., 2013).

It is not known how the combination of a suboptimal environment (such as hypoxia) and a plant-based diet (such as SBM-based diet) may affect digestive function and intestinal health in rainbow trout. In an experiment, changes in the intestinal morphology induced by dietary plant ingredients were found to be aggravated in Nile tilapia (Oreochromis niloticus) kept at hypoxia (Tran-Ngoc et al., 2016). In the current experiment, it is hypothesized that the effect of a dietary challenge on gut morphology and digestive function may be aggravated when rainbow trout is exposed to a challenging environment. This experiment was, therefore, conducted to evaluate whether exposure to hypoxia (induced by lowering the water flow rate) will aggravate the effect of a SBM-based diet as a dietary challenge on digestive function and intestinal morphology of rainbow trout.

\section{2 | MATERIALS AND METHODS}

The experiment was performed in accordance with the Dutch law on the use of experimental animals and approved by the ethical committee of Wageningen University for animal experiments (DEC: 2014006.a)

\subsection{Fish and rearing conditions}

Six hundred juvenile rainbow trout with mean initial body weight $( \pm S E)$ of $74.1 \pm 0.3 \mathrm{~g}$ were randomly allocated into 12 tanks (50 fish per tank) supplied with freshwater at the start of the experiment. The tanks were all connected to a recirculation system which allowed online measurement of actual and cumulative water flow per tanks, oxygen concentration, temperature, $\mathrm{pH}$ and conductivity. The details of measurement units and water sampling are described elsewhere (Saravanan et al., 2012).

Two isoenergetic and isonitrogenous diets were formulated: one fishmeal-based control (FM) and one containing $400 \mathrm{~g} \mathrm{~kg}^{-1}$ soybean meal (SBM) as experimental diet. Cellulose was added to the diets as a filler. Yttrium oxide $\left(\mathrm{Y}_{2} \mathrm{O}_{3}\right)$ was added to the diets as inert marker for digestibility calculations (Austreng, Storebakken, Thomassen, Refstie, \& Thomassen, 2000). The formulation and composition of the diets are shown in Table 1. The ingredients were ground in a hammer mill (Condux LHM20/16, Hanau, Germany) fitted with a 1-mm sieve. The diets were produced by Research Diet Service (Wijk bij Duurstede, the Netherlands) using a twin-screw extruder (Clextral, Firminy, France) equipped with a $3 \mathrm{~mm}$ die. The pellets were then dried in a tray-drier at $70^{\circ} \mathrm{C}$ for $3 \mathrm{hr}$ and cooled to ambient temperature. Restrictive feeding was used to ensure that the fish in all treatment groups consume the same amounts of feed and thus the same amount of SBM as a dietary challenge. The intention was to exclude the effect of feeding level on the degree of SBMIE and ADC values. The feeding rate was $15 \mathrm{~g} \mathrm{~kg}^{-1}$ mean biomass of 12 tanks during period 1 and was reduced to $12.5 \mathrm{~g} \mathrm{~kg}^{-1}$ at the start of period 2. Each diet was assigned randomly to triplicate tanks (200 L capacity) according to the treatments and fed to the fish manually twice daily throughout the experiment at 9:00 and 16:00 hr for maximum $1 \mathrm{hr}$. The water flow rate was set at $7.5 \mathrm{~L} \mathrm{~min}^{-1}$ for all tanks during period 1 . Photoperiod was maintained at $12 \mathrm{~L}: 12$ $\mathrm{D}$, water temperature at $14.0 \pm 0.5^{\circ} \mathrm{C}$ and $\mathrm{pH}$ between 7.0 and 7.5 throughout the experiment.

\section{2 | Experimental design}

The experiment consisted of four treatments and divided into two periods: period 1, was adaptation period of 28 days to diets and all fish were kept under optimal conditions by setting the water flow rate at $7.5 \mathrm{~L} \mathrm{~min}{ }^{-1}$ and period 2, an experimental period of 42 days where fish were subjected to either a dietary challenge and/or exposed to suboptimal environment by reducing the water flow rate from 7.5 to $2.25 \mathrm{~L} \mathrm{~min}^{-1}$. Water DO level is the key limiting factor when the water flow rate is reduced; however, this treatment also leads to accumulation of metabolites or fish excretions such as ammonia. To simplify nomenclature, low water flow rate is termed hypoxia $(\mathrm{HY})$ and optimal water flow rate is termed normoxia (NO). Thus, the four treatments tested in this experiment are as follows: 
TABLE 1 Diet formulation and chemical composition of experimental diets fed to rainbow trout (Oncorhynchus mykiss)

\begin{tabular}{|c|c|c|}
\hline & FM & SBM \\
\hline \multicolumn{3}{|l|}{ Ingredients $\left(\mathrm{g} \mathrm{kg}^{-1}\right)$} \\
\hline Fish meal $^{a}$ & 540.0 & 250.0 \\
\hline Soybean meal ${ }^{b}$ & - & 400.0 \\
\hline Wheat flour ${ }^{c}$ & 170.0 & 140.0 \\
\hline Rapeseed oil & 100.0 & 120.9 \\
\hline Fish oil $^{d}$ & 40.0 & 40.0 \\
\hline Cellulose & 143.4 & 30.0 \\
\hline Monocalciumphosphate ${ }^{\mathrm{e}}$ & - & 10.0 \\
\hline DL-methionine ${ }^{f}$ & - & 2.5 \\
\hline Yttrium oxide ${ }^{g}$ & 0.1 & 0.1 \\
\hline Vitamin/mineral premix ${ }^{\mathrm{h}}$ & 6.5 & 6.5 \\
\hline \multicolumn{3}{|l|}{ Proximate analysis } \\
\hline Dry matter $\left(\mathrm{g} \mathrm{kg}^{-1}\right)$ & 949 & 957 \\
\hline Crude protein $\left(\mathrm{g} \mathrm{kg}^{-1}\right)$ & 430 & 427 \\
\hline Crude lipid $\left(\mathrm{g} \mathrm{kg}^{-1}\right)$ & 206 & 220 \\
\hline $\begin{array}{l}\text { Non-starch polysaccharides } \\
\left(\mathrm{g} \mathrm{kg}^{-1}\right)^{i}\end{array}$ & 155 & 164 \\
\hline Starch $\left(\mathrm{g} \mathrm{kg}^{-1}\right)$ & 130 & 113 \\
\hline Ash $\left(\mathrm{g} \mathrm{kg}^{-1}\right)$ & 79 & 76 \\
\hline Gross energy (MJ kg-1) & 23.0 & 23.2 \\
\hline
\end{tabular}

FM, fishmeal; SBM, soybean meal.

${ }^{a}$ TripleNine Fish Protein, Esbjerg, Denmark.

${ }^{\mathrm{b}}$ Cargill, Amsterdam, the Netherlands.

'Meneba, Weert, the Netherlands.

${ }^{\mathrm{d} C}$ Coppens International, Helmond, the Netherlands.

${ }^{\mathrm{e}}$ Tessenderlo Chemie, Rotterdam, the Netherlands.

${ }^{f}$ Evonik Industries AG, Hanau, Germany.

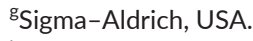

${ }^{h}$ Vitamin/mineral premix provided ( $\left.\mathrm{kg}^{-1} \mathrm{diet}\right)$ : $\alpha$-tocopherol acetate, $100 \mathrm{IU}$; sodium menadione bisulphate, $10 \mathrm{mg}$; retinyl acetate, 3,000 IU; cholecalciferol, 2,400 IU; thiamine, $10 \mathrm{mg}$; riboflavin, $10 \mathrm{mg}$; pyridoxine, $10 \mathrm{mg}$; nicotinic acid, $20 \mathrm{mg}$; folic acid, $2 \mathrm{mg}$; ascorbyl phosphate, $100 \mathrm{mg}$; inositol, $400 \mathrm{mg}$; biotin, $0.2 \mathrm{mg}$; pantothenic acid, $40 \mathrm{mg}$; cyanocobalamin, $0.015 \mathrm{mg}$; choline chloride, 2,000 mg; antioxidant BHT (E300-321), $100 \mathrm{mg}$; calcium propionate, 1,000 mg; $\mathrm{Fe}$ (as $\mathrm{FeSO}_{4} \cdot 7 \mathrm{H}_{2} \mathrm{O}$ ), $50 \mathrm{mg}$; $\mathrm{Zn}$ (as $\mathrm{ZnSO}_{4} \cdot 7 \mathrm{H}_{2} \mathrm{O}$ ), $30 \mathrm{mg}$; $\mathrm{Co}$ (as $\mathrm{CoSO}_{4} \cdot 7 \mathrm{H}_{2} \mathrm{O}$ ), $0.1 \mathrm{mg}$; $\mathrm{Cu}$ (as $\mathrm{CuSO}_{4} \cdot 5 \mathrm{H}_{2} \mathrm{O}$ ), $10 \mathrm{mg}$; Se (as $\mathrm{Na}_{2} \mathrm{SeO}_{3}$ ), $0.5 \mathrm{mg}$; $\mathrm{Mn}$ (as $\mathrm{MnSO}_{4} \cdot 4 \mathrm{H}_{2} \mathrm{O}$ ), $20 \mathrm{mg} ; \mathrm{Mg}$ (as $\mathrm{MgSO}_{4} .7 \mathrm{H}_{2} \mathrm{O}$ ), $500 \mathrm{mg} ; \mathrm{Cr}$ (as $\mathrm{CrCl}_{3} \cdot 6 \mathrm{H}_{2} \mathrm{O}$ ), $1 \mathrm{mg}$; I (as $\mathrm{CalO}_{3} \cdot 6 \mathrm{H}_{2} \mathrm{O}$ ), $2 \mathrm{mg}$. iCalculated non-starch polysaccharides $=1,000-$ (crude protein + crude lipid + starch + ash).

Treatment 1: Period 1, FM at normoxia $\rightarrow$ Period 2, FM at hypoxia (FMNO $\rightarrow$ FMHY)

Treatment 2: Period 1, FM at normoxia $\rightarrow$ Period 2, SBM at hypoxia

(FMNO $\rightarrow$ SBMHY)

Treatment 3: Period 1, FM at normoxia $\rightarrow$ Period 2, SBM at normoxia

(FMNO $\rightarrow$ SBMNO)

Treatment 4: Period 1, SBM at normoxia $\rightarrow$ Period 2, SBM at hypoxia $(\mathrm{SBMNO} \rightarrow \mathrm{SBMHY})$

Treatment 1 was designed to evaluate whether exposure to hypoxia alone would affect digestive function and impair intestinal health.
Treatments 2 and 3 were designed to evaluate whether change from FM to SBM is more detrimental to digestive function and SBMIE, as an indicator of diet-induced enteropathy, at hypoxia compared to normoxia. Treatment 4 was designed to evaluate whether under steady state dietary challenge any change in the environment from normoxia to hypoxia will aggravate digestive function and SBMIE.

Normoxia resulted in a mean water DO level of above $8 \mathrm{mg} \mathrm{L}^{-1}$ in the outlet (>78\% saturation). If necessary, pure oxygen was injected into the inlet to maintain the intended DO level. Hypoxia resulted in a mean water DO level of below $6 \mathrm{mg} \mathrm{L}^{-1}$ in the outlet ( $<55 \%$ saturation). The minimum DO level in the outlet, however, was maintained above $3.8 \mathrm{mg} \mathrm{L}^{-1}$ to avoid extreme reduction in feed intake and increased mortality. For this purpose, pure oxygen was injected into the inlet water. The mean of DO level (mean $\pm S D$ ) in the inlet was $10.3 \pm 0.3 \mathrm{mg} \mathrm{L}^{-1}$. Water parameters including daily oxygen concentration and $\mathrm{pH}$ and also during week five of period 2 , total ammonium nitrogen (TAN), nitrite and nitrate were measured for each tank by the method described elsewhere (Saravanan et al., 2012).

\section{3 | Sampling procedure}

Faeces collection was performed daily throughout the last 2 weeks of the period 1 and pooled to determine digestibility of nutrients in this period. The faeces collection continued throughout period 2 at four sampling time points, days 0-7, 8-14, 15-21 and 22-42 (faeces samples collected daily and were pooled within these periods). Each tank was connected to one settling tank as previously described (Saravanan et al., 2012). A faecal collection bottle (250 ml) was attached to the bottom of the settling tank while placed in a thermostatic box connected to a cooling system to avoid the bacterial degradation of nutrients in the faeces. The faeces collected within weeks from each tank was pooled in the same tray and stored at $-20^{\circ} \mathrm{C}$ in an aluminium box until further analysis. The settling tank was also used to check and count the uneaten pellets in the respective respiration tank at every feeding for accurate calculation of feed intake. For this purpose, another set of 250-ml bottles were attached to the settling tanks during feeding.

Distal intestine tissue samples from three fish were taken per tank on days $0,7,14,21$ and 42 of period 2 . The tissue samples were fixed in neutral buffered formalin (40 $\mathrm{g} \mathrm{L}^{-1}$ formaldehyde) and embedded in paraffin before staining by haematoxylin and eosin (H\&E). Blinded evaluation and scoring of the following five morphological parameters was performed on each tissue:

1. Subepithelial infiltration of leucocytes: increased accumulation of leucocytes in the subepithelial area down to stratum compactum.

2. Supranuclear vacuolization (SNV) of epithelial cells: reduced vacuolization of the epithelial cells.

3. Atrophy of intestinal folds.

4. Vacuolar degeneration of the epithelial cells: increased vacuolar degeneration in the base of the intestinal folds. 
5. The presence, if any, of granulomatous change and the degree of this change: increased accumulation of fibroblasts, macrophages and presence of giant cells in the subepithelial area.

A score was given to each parameter which ranged from 0 to 3 . Increase in the score of each parameter indicates a more severe morphological changes. The overall histopathology score for each fish was calculated by taking the average score of the morphological parameters to express the degree of change in that individual.

\section{4 | Analytical procedure}

Feed and oven-dried faeces samples were ground in a blender before further analysis. Dry matter was determined by drying the samples for $4 \mathrm{hr}$ at $103^{\circ} \mathrm{C}$ until a constant weight was obtained. Crude protein was determined by the Kjeldahl method based on $N$ content $\times 6.25$ (ISO 5983/NEN 3145). Feed and faecal samples were hydrolysed by $3 \mathrm{~N} \mathrm{HCl}$ before crude fat analysis as described in Saravanan et al. (2012). Crude fat content was measured following petroleum-ether extraction (Soxhlet method). Gross energy content was determined using a bomb calorimeter (IKA-C7000, IKA-Aanalysentechnik, Weitersheim, Germany). Gross ash was determined after combustion of dried samples in a muffle furnace at $550^{\circ} \mathrm{C}$ (ISO 5984/NEN 3323). Yttrium was measured by inductively coupled plasma mass spectrometry (ICP-MS) after acid digestion of feeds and faeces. Starch content was determined enzymatically as glucose, liberated by $\alpha$-amylase and amyloglucosidase hydrolysis (AOAC Method 996.11).

\subsection{Calculations and statistics}

Apparent digestibility coefficients (ADC, \%) were calculated as:

$$
A D C_{X}=\left(1-Y_{\text {diet }} / Y_{\text {faeces }} \times X_{\text {faeces }} / X_{\text {diet }}\right) \times 100
$$

where $X$ represents dry matter, crude protein, crude lipid, starch or energy, $Y_{\text {diet }}$ and $Y_{\text {faeces }}$ represent the yttrium concentrations in the diet and faeces, respectively, and $X_{\text {diet }}$ and $X_{\text {faeces }}$ are the concentrations of $X$ in the diet and faeces, respectively.

Feed conversion ratio was calculated as:

$$
\text { FCR }=\text { Feed intake }(g, D M) \times \text { fish weight gain }(g)^{-1}
$$

Daily feed intake (g DM) is expressed per kg current body weight $\left(B W_{n}\right)$ : daily feed intake (g DM) divided by $B W_{n}$.

$\mathrm{BW}_{\mathrm{n}}$ was calculated as follows:

$$
\mathrm{BW}_{\mathrm{n}}=\mathrm{BW}_{\mathrm{n}-1}+\left(\text { daily feed intake, } \mathrm{gDM} \times \mathrm{FCR}^{-1}\right) \text {. }
$$

Statistical analyses were performed using SAS 9.4 (SAS Institute, Cary, NC, USA). All data were tested for normality and homogeneity by Kolmogorov-Smirnov and Bartlett tests. Data from ADC of dry matter in period 1 and overall histopathological score violated the normal distribution assumption after log10-transformation; and thus, these data were subjected to nonparametric Kruskal-Wallis test followed by multiple pairwise comparisons (Dwass-Steel-Critchlow-Fligner) if the test was significant. ADC of crude protein, lipid, starch, ash and energy were subjected to one-way analysis of variance (ANOVA) in GLM procedure to test the effect of dietary treatment in period 1 . The effect of treatment and sampling time on ADC of dry matter, crude protein and ash in period 2 was analysed using a two-way ANOVA in GLM procedure. ADC of lipid and starch at the end of period 2 (days 22-42) were subjected to a one-way ANOVA. Least square means comparison was used to determine which groups differed significantly from each other. Regression analysis was performed to determine the variables that correlated with feed intake at the end of period 2. Differences were declared statistically significant if $p<.05$.

\section{3 | RESULTS}

\subsection{Water quality parameters}

The water $\mathrm{pH}$ level remained stable (ranged from 7.0 to 7.5 ) throughout the experiment (periods 1 and 2) for all treatment groups and hypoxia did not change the $\mathrm{pH}$ level $(p>.05)$. The fluctuations in $\mathrm{pH}$ were too small to have had a significant effect on toxicity of TAN. The water DO level (expressed as $\mathrm{mg} \mathrm{L}^{-1}$ ) was above $7.0 \mathrm{mg} \mathrm{L}^{-1}$ during period 1 in all tanks (Figure 1). At the start of period 2, water Do level was reduced to below $5 \mathrm{mg} \mathrm{L}^{-1}$ immediately after reduction in water flow rate in the tanks assigned to hypoxia and remained between 4 and $5 \mathrm{mg} \mathrm{L}^{-1}$ during this period (Figure 2). Peaks were observed, however, on the oxygen curve corresponding to the DI tissue sampling days. The mean water concentration of TAN during week five of period 2 was significantly higher at hypoxia compared to that observed at normoxia ( $p=.002$ ) (Figure 3). During the same week, water level of nitrite and nitrate at hypoxia were $0.008 \pm 0.0003$ and $0.22 \pm 0.015 \mathrm{mg} \mathrm{N} \mathrm{L}^{-1}$ (mean $\pm S E, n=9$ tanks), respectively. At normoxia, the concentrations were $0.007 \pm 0.0009$ and $0.18 \pm 0.016 \mathrm{mg} \mathrm{N} \mathrm{L}^{-1}$ (mean $\pm S E$, $n=3$ tanks). The difference in concentration of nitrite and nitrate was insignificant among treatments.

\subsection{Feed intake and growth}

Daily feed intake ( $\mathrm{g} \mathrm{kg}^{-1}$ body weight) of FM- and SBM-fed fish remained stable throughout period 1 (Figure 1). The mean feed intake (g fish ${ }^{-1}$ day $^{-1}$ ) over period 1 was not changed significantly in response to diet ( $p>.05$ ) (Table 2). In period 1, there was no significant difference in weight gain ( $\mathrm{g}$ fish ${ }^{-1}$ day $^{-1}$ ) between fish fed FM and SBM diet $(p>.05)$

Daily feed intake ( $\mathrm{g} \mathrm{kg}^{-1}$ body weight) of all treatment groups was not significantly changed during period 2; however, it was reduced in fish fed FM and SBM diets and kept at hypoxia during the last 2 weeks of period 2 (Figure 2). Feed intake in fish subjected to change from $\mathrm{FM}$ to SBM at normoxia (FMNO $\rightarrow$ SBMNO) in period 2 remained unchanged for the whole period. The mean feed intake ( $\mathrm{g} \mathrm{fish}^{-1} \mathrm{day}^{-1}$ ) in period 2 was significantly higher in the fish fed SBM at normoxia (FMNO $\rightarrow$ SBMNO) than that in other treatment groups (i.e., fish kept at hypoxia) $(p=.014)$. 

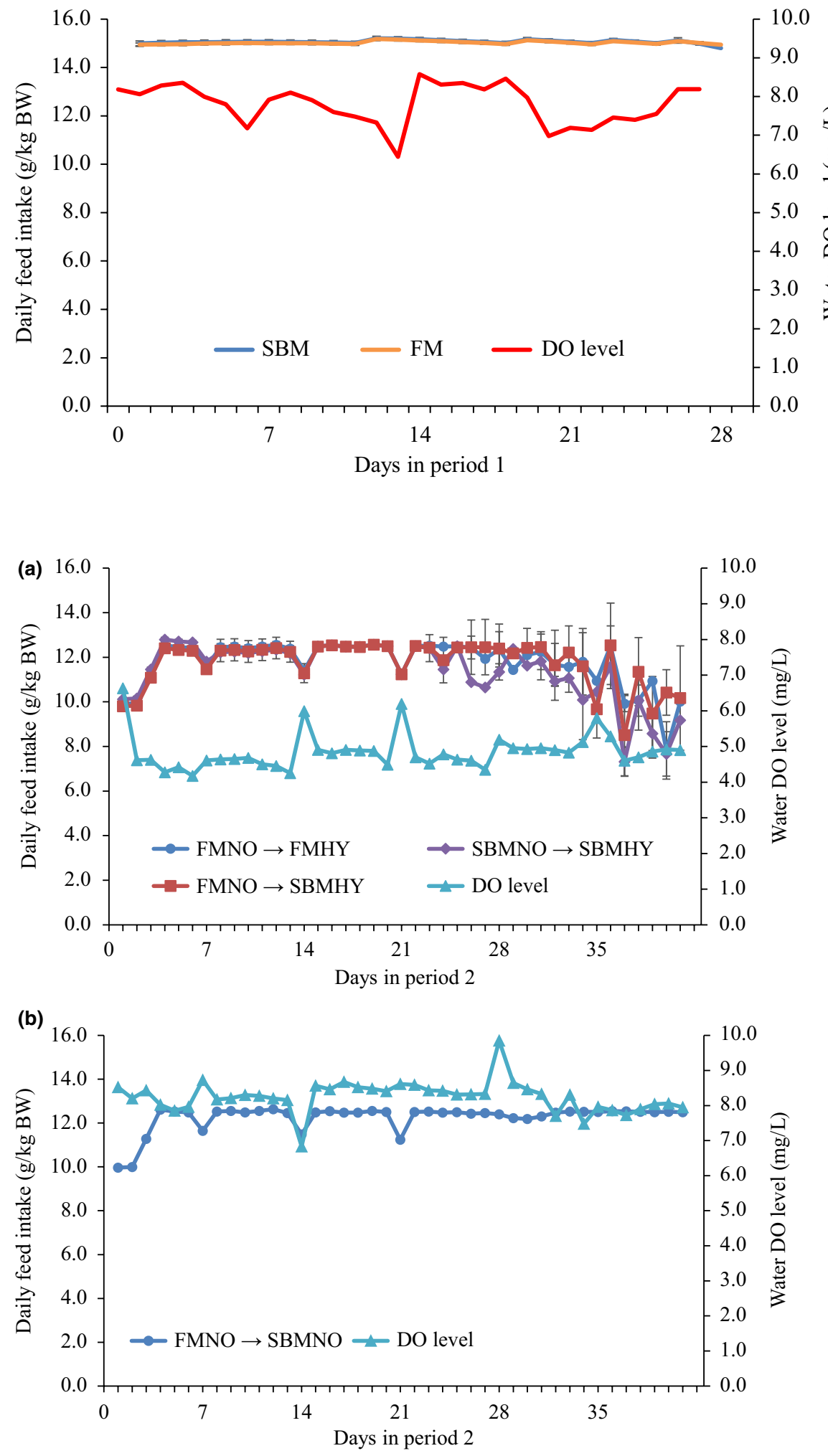

FIGURE 1 Daily feed intake

( $\mathrm{g} \mathrm{kg}^{-1}$ body weight) of rainbow trout (Oncorhynchus mykiss) (means $\pm S E$ ) fed fish meal (FM) or soybean meal (SBM) and kept at normoxia (high water flow rate) in period 1. Each data point on diet curves is the mean of three tanks for 1 day. The DO level is the mean of all tanks ( $n=12$ )
FIGURE 2 Daily feed intake ( $\mathrm{g} \mathrm{kg}^{-1}$ body weight) of rainbow trout (Oncorhynchus mykiss) (means $\pm S E$ ) subjected to change in diet and/or environment (hypoxia) in period 2. (a) Treatment groups subjected to challenging environment (hypoxia). One treatment remained on the fish meal (FM) diet supplied in period 1 (steady state dietary condition) (FMNO $\rightarrow$ FMHY). One treatment group was subjected to change from FM diet to soybean meal (SBM) diet (FMNO $\rightarrow$ SBMHY) and another treatment remained on SBM diet (steady state dietary challenge) (SBMNO $\rightarrow$ SBMHY). (b) Treatment group kept at normoxia. Fish in this group was subjected to change from FM diet supplied in period 1 to SBM diet $(\mathrm{FMNO} \rightarrow \mathrm{SBMNO}$ ) in period 2. Each data point is the diet mean of three tanks for 1 day. The DO line in (a) is the mean of all low flow tanks in period $2(n=9)$ and in (b) is the mean of high flow tanks $(n=3)$
Regression analysis revealed that feed intake showed reduction with increasing TAN concentration $\left(R^{2}=.45, p=.02\right)$ (Figure 4). However, no significant relation was found between changes in feed intake and water DO level $\left(R^{2}=.25, p=.1\right), \mathrm{pH}\left(R^{2}=.15, p=.21\right)$, ADC of crude protein $\left(R^{2}=.08, p=.36\right)$, dry matter $\left(R^{2}=.15, p=.20\right)$, lipid $\left(R^{2}=.01, p=.72\right)$ and $\operatorname{starch}\left(R^{2}=.03, p=.58\right)$ at the end of period 2 .

\section{3 | Histopathological evaluation}

The changes in histopathological scores over time are shown in Figure 5. These changes were confined to the distal intestine and characterized by reduced apical SNV, reduced height of simple and complex intestinal folds (partial atrophy), and increased number of 
FIGURE 3 Total ammonia nitrogen (TAN) level in each treatment group during week five of period 2. Ambient TAN level increased $(p=.002)$ in the three treatments exposed to hypoxia regardless of their dietary regimen. Values are mean $(n=3) \pm S E$

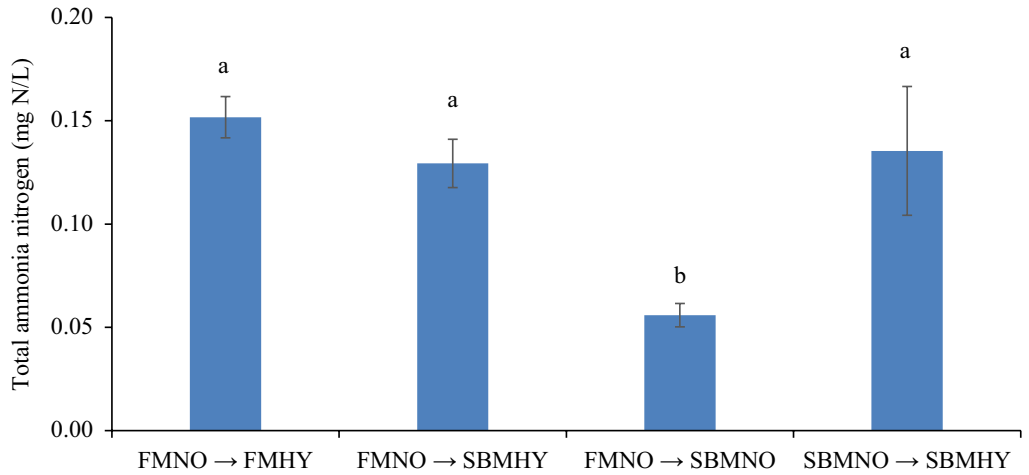

TABLE 2 Feed intake, feed efficiency and growth in rainbow trout (Oncorhynchus mykiss) in periods 1 and $2^{1}$

\begin{tabular}{|c|c|c|c|c|c|c|}
\hline Treatments & FMNO $\rightarrow$ FMHY & $\mathrm{FMNO} \rightarrow \mathrm{SBMHY}$ & FMNO $\rightarrow$ SBMNO & $\mathrm{SBMNO} \rightarrow \mathrm{SBMHY}$ & Pooled SEM & $p$-value \\
\hline Initial weight (g fish ${ }^{-1}$ ) & 74 & 75 & 74 & 73 & 1 & .65 \\
\hline Final weight (g fish ${ }^{-1}$ ) & 211 & 205 & 208 & 192 & 13 & .10 \\
\hline Weight gain (g fish ${ }^{-1}$ day $^{-1}$ ) & 1.70 & 1.71 & 1.70 & 1.66 & 0.03 & .44 \\
\hline Feed intake (g DM fish ${ }^{-1}$ day $^{-1}$ ) & 1.28 & 1.28 & 1.28 & 1.29 & 0.00 & .48 \\
\hline \multicolumn{7}{|l|}{ Period 2} \\
\hline Weight gain (g fish ${ }^{-1}$ day $^{-1}$ ) & 2.03 & 1.98 & 2.10 & 1.75 & 0.31 & .10 \\
\hline Feed intake (g DM fish ${ }^{-1}$ day $^{-1}$ ) & $1.74^{\mathrm{ab}}$ & $1.67^{\mathrm{ab}}$ & $1.85^{\mathrm{a}}$ & $1.60^{b}$ & 0.08 & .01 \\
\hline FCR & 0.82 & 0.84 & 0.89 & 0.93 & 0.11 & .33 \\
\hline
\end{tabular}

${ }^{1}$ Values represent the means $(n=3)$ with pooled SEM. Means in a row with different lower case letters indicate significant difference among treatments $(p<.05)$.



FIGURE 4 The regression of water total ammonia nitrogen (TAN) level against feed intake ( $\mathrm{g} \mathrm{kg}^{-1}$ body weight) during week five of period 2

leucocytes (e.g., lymphocytes, granulocytes and eosinophilic granular cells) in the subepithelial area, the degree of vacuolar degeneration in the base of the folds and the degree of granulomatous change, if present. Exact mean histopathological scores for all treatment groups are given in Table $\mathrm{S} 1$.

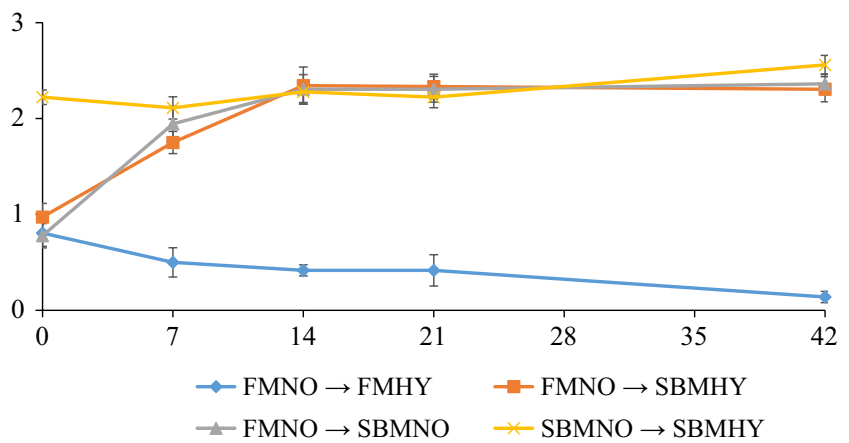

FIGURE 5 Morphological changes in the distal intestine of rainbow trout (Oncorhynchus mykiss) ( $n=9$ fish/treatment) over time. Scores are based on average of the five parameters used in evaluation of SBMIE: subepithelium infiltration of leucocytes, supranuclear vacuolization of apical epithelial cells, atrophy of intestinal folds, the degree of basal-fold vacuolar degeneration, and granuloma. Fish was challenged with soybean meal and/or hypoxia during period 2. NO, normoxia; HY, hypoxia. Values at day 0 are histopathological scores at the end of period 1

Exposure to hypoxia did not exert adverse effect on morphological changes in fish fed FM throughout the experiment (steady state diet), but exposed to hypoxia during period 2 (FMNO $\rightarrow$ FMHY) $(p>.05$ ). Fish fed the SBM diet during period 1, however, developed SBMIE 
TABLE 3 Apparent digestibility coefficients (ADC, \%) of nutrients and energy of rainbow trout (Oncorhynchus mykiss) subjected to change in diet and/or environment ${ }^{1}$

\begin{tabular}{|c|c|c|c|c|c|}
\hline Treatments & $\mathrm{FMNO} \rightarrow \mathrm{FMHY}$ & $\mathrm{FMNO} \rightarrow \mathrm{SBMHY}$ & FMNO $\rightarrow$ SBMNO & $\mathrm{SBMNO} \rightarrow \mathrm{SBMHY}$ & Pooled SEM \\
\hline \multicolumn{6}{|l|}{ Dry matter } \\
\hline Period $1^{2,3}$ & 72.3 & 72.1 & 72.0 & 79.2 & 2.5 \\
\hline Day 7 & $74.6^{\mathrm{B}, \mathrm{c}}$ & $82.6^{\mathrm{A}, \mathrm{a}}$ & $81.7^{\mathrm{AB}, \mathrm{a}}$ & $80.3^{\mathrm{B}, \mathrm{b}}$ & 2.3 \\
\hline Day 14 & $75.5^{\mathrm{B}, \mathrm{c}}$ & $81.7^{\mathrm{B}, \mathrm{a}}$ & $81.1^{\mathrm{AB}, \mathrm{ab}}$ & $79.7^{\mathrm{B}, \mathrm{b}}$ & 0.8 \\
\hline Day 42 & $78.0^{A, b}$ & $81.9^{\mathrm{AB}, \mathrm{a}}$ & $82.8^{\mathrm{A}, \mathrm{a}}$ & $82.1^{\mathrm{A}, \mathrm{a}}$ & 0.5 \\
\hline \multicolumn{6}{|l|}{ Crude protein } \\
\hline Period $1^{2}$ & $92.9^{b}$ & $92.7^{\mathrm{b}}$ & $92.2^{\mathrm{b}}$ & $94.3^{\mathrm{a}}$ & 0.6 \\
\hline \multicolumn{6}{|l|}{ Period 2} \\
\hline Day 7 & $94.3^{b}$ & $96.2^{\mathrm{a}}$ & $95.0^{b}$ & $95.9^{\mathrm{a}}$ & 0.4 \\
\hline \multicolumn{6}{|l|}{ Ash } \\
\hline Period $1^{2}$ & $51.2^{\mathrm{b}}$ & $50.9^{b}$ & $50.5^{b}$ & $57.8^{\mathrm{a}}$ & 0.9 \\
\hline \multicolumn{6}{|l|}{ Period 2} \\
\hline Day 7 & $52.1^{\mathrm{B}, \mathrm{b}}$ & $57.8^{\mathrm{B}, \mathrm{a}}$ & $56.6^{\mathrm{a}}$ & $59.0^{\mathrm{a}}$ & 1.1 \\
\hline Day 14 & $55.8^{\mathrm{AB}}$ & $58.1^{\mathrm{B}}$ & 57.3 & 59.1 & 1.5 \\
\hline Day 21 & $56.1^{A B}$ & $57.9^{B}$ & 57.4 & 58.8 & 1.5 \\
\hline Day 42 & $57.9^{\mathrm{A}}$ & $60.4^{\mathrm{A}}$ & 58.6 & 60.2 & 1.3 \\
\hline \multicolumn{6}{|l|}{ Gross energy 4} \\
\hline \multicolumn{6}{|l|}{ Lipid } \\
\hline Period $1^{2}$ & $93.7^{a}$ & $93.5^{a}$ & $94.8^{\mathrm{a}}$ & $89.0^{b}$ & 1.2 \\
\hline
\end{tabular}

${ }^{1}$ Values represent the means $(n=3)$ with pooled SEM. Means in a row with different lower case letters indicate significant difference among treatments in period 1 (one-way ANOVA, $p<.05$ ) and in period 2 (two-way ANOVA, $p<.05$ ). Means in each column with different capital letters indicate significant difference over time during period 2 within a treatment. ADC of starch and lipid for the end of period 2 (days 22-42) are presented in Figure 6 (one-way ANOVA). Results of the ANOVA (exact $p$-values) are shown in Table 4.

${ }^{2}$ Fish were fed either fish meal (FM) or soybean meal (SBM) for 4 weeks during period 1.

${ }^{3} \mathrm{~A}$ Kruskal-Wallis one-way ANOVA was used for ADC of dry matter in period 1.

${ }^{4}$ Mean of gross energy digestibility coefficient includes the effect of cellulose inclusion as an inert ingredient.

in the DI. The degree of SBMIE remained unchanged in this treatment group over time during period 2 where the fish was exposed to hypoxia (SBMNO $\rightarrow$ SBMHY) ( $p>$.05). The two groups of fish subjected to change from $\mathrm{FM}$ to SBM, regardless of their environment (i.e., FMNO $\rightarrow$ SBMHY and FMNO $\rightarrow$ SBMNO) showed similarly increased histopathological score over time in period 2. By day 14 , they reached the same degree of SBMIE as in fish fed SBM throughout the experiment but exposed to suboptimal condition (SBMNO $\rightarrow$ SBMHY) (Figure 5). Thus, the degree of SBMIE was stable and similar from day 14 onwards among fish challenged with SBM during period 2 , regardless of their environmental conditions.

\section{4 | Digestibility}

There was no significant effect of diets on the ADC of starch in period 1 (Table 3); however, ADC of lipid were reduced in fish fed SBM compared to the fish fed FM ( $p=.0001)$. The effect of treatments on ADC of dry matter, crude protein, ash and energy during period 1 is shown in Table 3. ADC of crude protein, ash and energy were higher in fish fed SBM $(p<.05)$ compared with those fed the FM diets, while the ADC of dry matter tended to increase in these fish $(p=.08)$.

During period 2 , there was no significant difference in any of the ADC values of the fish subjected to change from FM to SBM diet and exposed 
FIGURE 6 Apparent digestibility of starch and lipid of rainbow trout (Oncorhynchus mykiss) subjected to change in diet and/or hypoxia at the end of period 2. Values are means $(n=3) \pm S E$

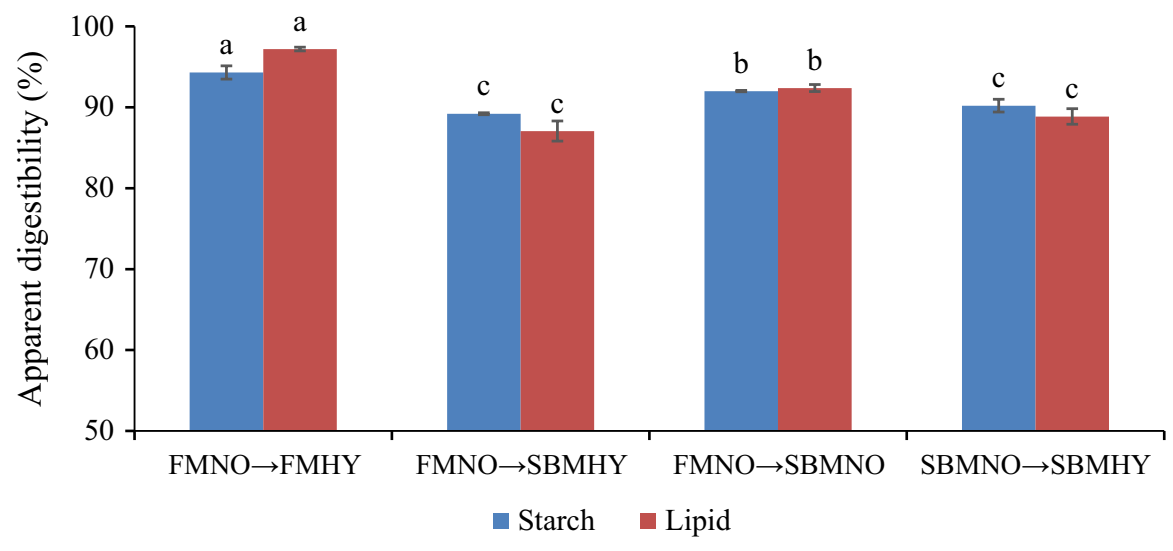

to hypoxia (FMNO $\rightarrow$ SBMHY) and of the fish subjected to hypoxia and fed SBM diet throughout the experiment (SBMNO $\rightarrow$ SBMHY). The fish subjected simultaneously to changes in diet and environment (FMNO $\rightarrow$ SBMHY) and the fish fed SBM continuously (steady state), but subjected to hypoxia in period 2 (SBMNO $\rightarrow$ SBMHY) showed the lowest ADC of lipid and starch at the end of period 2 (Figure 6). ADC of lipid and starch were highest in the group fed FM throughout the experiment, but exposed to hypoxia (FMNO $\rightarrow$ FMHY) $(p=.001)$. ADC values of lipid and starch were higher in the fish subjected to dietary change from FM to SBM and kept at normoxia (FMNO $\rightarrow$ SBMNO) than in the fish fed SBM and exposed to hypoxia during period 2 (FMNO $\rightarrow$ SBMHY and SBMNO $\rightarrow$ SBMHY) $(p=.002)$. In the fish fed FM throughout the experiment but exposed to hypoxia in period 2 (FMNO $\rightarrow$ FMHY), the ADC of dry matter reached its highest value by day 42. ADC of dry matter were, however, gradually reduced from days 7 to 21 in the fish subjected to changes in both diet and environment (FMNO $\rightarrow$ SBMHY). Similar trend was also observed in the fish challenged by SBM but kept at normoxia (FMNO $\rightarrow$ SBMNO). There were, however, no differences in ADC of dry matter among any groups challenged by SBM regardless of the type of the environment by day 42. ADC of crude protein and ash in all treatment groups remained unchanged throughout period 2. ADC of crude protein were, however, highest in groups fed SBM at hypoxia (FMNO $\rightarrow$ SBMHY and SBMNO $\rightarrow$ SBMHY) at all time points and lowest in fish fed FM (steady state), but subjected to change to hypoxia (FMNO $\rightarrow$ FMHY). At hypoxia, changing from FM to SBM increased the ADC of ash significantly at day 7 compared to steady state FM feeding (FMNO $\rightarrow$ FMHY). The difference in ADC of ash was insignificant among treatments by day 42 . ADC of energy were found to be highest in the fish challenged by SBM and kept at normoxia (FMNO $\rightarrow$ SBMNO) $(p=.01)$; however, no significant difference was observed among other treatments $(p>.05)$. The interaction between treatments and sampling time was only significant for ADC of dry matter $(p>.05)$ (Table 4).

\section{4 | DISCUSSION}

This study was performed to investigate whether exposure to suboptimal environment (i.e., hypoxia) aggravates the effect of SBM on digestive function and intestinal enteropathy in rainbow trout over
TABLE 4 Results of the statistical analyses (one- and two-way ANOVA) for apparent digestibility coefficients (ADC) of nutrients and energy of rainbow trout (Oncorhynchus mykiss) subjected to change in diet and/or environment

\begin{tabular}{|c|c|c|c|}
\hline & \multicolumn{3}{|c|}{ Effects ( $p$-values) } \\
\hline & Treatment & Time & Treatment $\times$ Time \\
\hline \multicolumn{4}{|l|}{ Period $1^{a}$} \\
\hline Dry matter & 0.079 & - & - \\
\hline Crude protein & 0.003 & - & - \\
\hline Ash & 0.002 & - & - \\
\hline Gross energy & 0.001 & - & - \\
\hline Starch & 0.420 & - & - \\
\hline Lipid & 0.001 & - & - \\
\hline \multicolumn{4}{|l|}{ Period $2^{b}$} \\
\hline Dry matter & $<0.0001$ & $<0.0001$ & $<0.0001$ \\
\hline Crude protein & $<0.0001$ & 0.3403 & 0.8582 \\
\hline Ash & $<0.0001$ & $<0.0001$ & 0.0690 \\
\hline Starch & 0.0003 & - & - \\
\hline Lipid & 0.0001 & - & - \\
\hline Gross energy & 0.0100 & - & - \\
\hline
\end{tabular}

${ }^{a}$ Fish were fed either fish meal (FM) or soybean meal (SBM) for 4 weeks during period 1. One-way ANOVA was used for all ADC values to test the effect of treatment in period 1.

${ }^{\mathrm{b}}$ The fish were subjected to change in diet, environment or both for 42 days in period 2. ADC of dry matter, crude protein and ash in period 2 were subjected to two-way ANOVA to test the effect of treatment, sampling time and their interaction. One-way ANOVA was used for data from ADC of starch, lipid and gross energy (pooled faeces samples from days 22 to 42 ) in this period.

time. We evaluated the gastrointestinal status by monitoring digestive function and progression of SBMIE in rainbow trout in response to the challenges over time.

It is known that oxygen is less available to aquatic than airbreathing animals, and the uptake of oxygen from water is more challenging (Kramer, 1987). Thus, it is likely that reduction in DO level in this study was a challenging factor. We observed that the fish activity (locomotion) was lower in the hypoxia tanks. This is in accordance 
with previous observations of Nile tilapia kept at different degrees of hypoxia (Tran-Duy et al., 2012). Reduced activity of the fish could be a response to reduced DO level as a mechanism of adaptation (Kramer, 1987). Reduction in feed intake is another response which is reported to occur under hypoxic conditions (Tran-Duy et al., 2012) as feed intake is an oxygen demanding process. In this study, however, the feed intake during the 4 weeks after exposure to hypoxia remained unchanged in all treatment groups, indicating that low DO level did not affect feed intake. Fish were fed restrictively which explains why the low DO level did not adversely affect feed intake. Glencross (2009) reported that feed intake under hypoxia did not differ from normoxia when fish were fed restrictively for 28 days. However, in the same study, a significant reduction in feed intake was reported under hypoxia when fish were fed to apparent satiety. Thus, in this experiment restrictive feeding was performed to ensure that feed intake is not altered under hypoxic conditions to exclude the effect of feeding level on diet-induced enteropathy and nutrient digestibility. The reduction in feed intake during the last 2 weeks of period 2, however, could be a response to accumulation of ammonia due to the reduced water flow rate. Previous publications have reported adverse effect of elevated environmental ammonia level on feed intake in rainbow trout (Ortega, Renner, \& Bernier, 2005) and European sea bass (Dicentrarchus labrax) (Dosdat et al., 2003) and juvenile lake trout (Salvelinus namayeush) (Beamish \& Tandler, 1990). The highest TAN concentration in this study was well below the levels tested in those experiments; however, the slight but significant accumulation of ammonia may have been a challenging factor to the fish already affected by reduced DO level at hypoxia. Thus, it is possible that the combination of increased TAN and reduced water DO level caused reduction in feed intake in this experiment. Kolarevic et al. (2013) also showed that exposure to sublethal levels of TAN at normoxic condition did not change feed intake significantly in Atlantic salmon.

The development of SBMIE in rainbow trout fed the SBM diet during period 1 was expected and coincided with previous findings (Baeverford \& Krogdahl, 1996; Romarheim et al., 2008). Exposure to hypoxia in this experiment did not aggravate SBMIE in fish fed SBM. The lack of interactive effect between SBM and hypoxia in period 2 could be due to the high inclusion level of SBM $(400 \mathrm{~g} \mathrm{~kg}-1)$ used in the present experiment leading to histopathology score of 2 or higher in all fish from day 14. Thus, it was difficult to evaluate the impact of additional environmental challenge induced by reduced water flow on intestinal health. Furthermore, feeding FM at hypoxia did not result in any signs of inflammation in the DI of rainbow trout. Sundh et al. (2010) reported atrophy of intestinal folds in Atlantic salmon kept at hypoxia and temperature of $16^{\circ} \mathrm{C}$ (corresponding to $50 \%$ saturation). It is possible that rainbow trout is more resistant to the adverse change in the environmental conditions such as hypoxia than Atlantic salmon. SBM diet, however, induced significant morphological changes after 7 days of period 2 in fish subjected to SBM independent of the environment, which is in agreement with the study in Atlantic salmon (Urán et al., 2009). At day 14 and onward, all SBM-fed fish had similar histopathology score regardless of their environment, implying that there was no effect of feed intake, steady state SBM consumption and suboptimal conditions (reduced water flow rate) on this parameter, even at longer time of exposure.
The reduction in ADC of lipid in fish fed SBM compared to the fish fed FM in period 1 confirms previous reports (Øverland et al., 2009; Refstie, Storebakken, \& Roem, 1998; Romarheim et al., 2006). This trend was also observed 42 days after the change from the FM to SBM diet at normoxia and hypoxia. The ADC of starch in this study were close to the values previously reported in rainbow trout (Krogdahl, Sundby, \& Olli, 2004; Romarheim et al., 2006). Earlier publications have shown that starch can be highly digestible for carnivorous fish after hydrothermal treatment of the feed resulting in starch gelatinization (Bergot \& Breque, 1983; Panserat, 2009). Furthermore, lower intake of dietary starch under restrictive feeding has also reported to improve ADC of starch (Bergot \& Breque, 1983). The fact that ADC of starch did not differ significantly between SBM and FM during period 1 is in accordance with some earlier studies (Romarheim et al., 2006, 2012). The further reduction in ADC of lipid and starch in two groups of fish kept at hypoxia and fed SBM (steady state and subject to change from FM to SBM) suggests that there is an adverse additive effect of dietary challenge and suboptimal environment in the present study on digestive function of the fish. The degree of SBMIE did not differ between hypoxia- and normoxia-treated fish. This indicates that the changes in ADC of lipid and starch are independent of SBMIE. A possible explanation is that reduced activity of the fish at hypoxia may have led to slower gastrointestinal peristaltic movement than that at normoxia, which consequently increased the interaction time of lipids and starch with ANFs including NSPs in SBM diet. This in turn aggravated the adverse effect of ANFs on ADC of these nutrients. There are different types of ANFs in SBM, the function of which are not yet fully understood (Francis, Makkar, \& Becker, 2001). Some fraction of ANFs may interact with components essential for lipid digestion and reduce the ADC of lipid. An example is saponins which have been suggested to reduce lipase activity, leading to reduced ADC of lipid (Han, Xu, Kimura, Zheng, \& Okuda, 2000). NSPs may also reduce digestibility of different nutrients such as starch by increasing the viscosity of the digesta (Leenhouwers, Adjei-Boateng, Verreth, \& Schrama, 2006) or reducing brush border enzymes activity and bile acid concentration (Kraugerud et al., 2007). Another explanation is that at hypoxia, reduced water DO level contributed to further reduction in ADC of lipid due to higher oxygen demand of dietary lipids for oxidation. On the other hand, storage of dietary starch energy in the form of body fat is also more oxygen demanding than deposit of dietary fat (Reeds, Wahle, \& Haggarty, 1982). The suboptimal environment may also have increased the interactions between carbohydrates and lipids in the GIT, resulting in amylose-lipid complexes, which has shown to increase resistance of amylose to $\alpha$-amylase (Holm et al., 1983). Overall, this result also indicates that digestive function is more sensitive than the DI enteropathy in rainbow trout exposed to a dietary challenge under suboptimal conditions.

The lower ADC of crude protein in fish fed the FM diet during period 1 compared to the fish fed the SBM diet contradicts previous results (Øverland et al., 2009). Cellulose inclusion level was relatively high in the FM diet, but Hansen and Storebakken (2007) showed that cellulose does not affect ADC of protein, lipid and starch. Reduced ADC of FM compared to SBM may be due to the faeces collection method used in this experiment. In this experiment, faeces were collected in bottles mounted to the settling tanks and remained in the bottle for $23 \mathrm{hr}$ which may result in leaching of nutrients. Leaching has been discussed 
previously as a problem associated with the use of columns for faeces collection (Storebakken et al., 1998; Vandenberg \& De La Noüe, 2001). The same method of faeces collection was used in this experiment for all treatment groups; however, leaching rate of nitrogen may differ for different diets. Physical and chemical properties of the faecal matter from SBM diet are different from that of FM diet. For example, SBM diet has shown to contain less dry matter due to diarrhoea (Refstie, Sahlström, Bråthen, Baeverfjord, \& Krogedal, 2005; Refstie et al., 2000). The properties of faecal matter from SBM diet may have resulted in a higher rate of nitrogen leaching than for that for FM diet. This proposed effect of faeces collection method, however, was not reflected in ADC of starch and lipid. The observed stability in ADC of crude protein during the first 4 weeks of period 2 may be explained by the stable feed intake during this period. However, reduction in feed intake during the last 2 weeks of period 2 did not affect ADC of crude protein in fish kept at hypoxia regardless of the diet. The finding is in accordance with a previous report of no change in ADC of crude protein in European sea bass with chronic exposure to high water TAN level (Dosdat et al., 2003).

The higher ADC of dry matter and energy in fish fed the SBM diet in the present experiment may be a result of the high inclusion level of cellulose in the FM diet. The results are in agreement with Glencross, Rutherford, and Bourne (2012) whom also showed reduced ADC of dry matter and energy with higher percentage of cellulose in diet. However, the results show no significant difference in ADC of energy after 42 days of feeding in period 2 among the fish fed FM and SBM (steady state and subject to change from FM to SBM) at hypoxia. The reason for this observation may be the overall result of lower ADC of lipid and starch in fish subjected to SBM at hypoxia and reduced ADC of dry matter and crude protein in the fish fed FM at the same environment.

\section{5 | CONCLUSIONS}

To conclude, the suboptimal environment used in this experiment did not induce or aggravate the changes associated with SBMIE or adversely affect the ADC of nutrients in rainbow trout. However, fish subjected to the dietary challenge at suboptimal environment showed further reduction in digestibility of starch and lipid without change in the degree of SBMIE when compared to the fish exposed to dietary challenge alone. These results indicate that there was an interaction between feeding plant-based diets and exposure to suboptimal environmental condition on digestive function of rainbow trout.

\section{ACKNOWLEDGEMENTS}

This study was funded by AQUAEXCEL (Aquaculture Infrastructures for Excellence in European Fish Research) project no 0071/05/13/30/A and also supported by Foods of Norway, a Centre for Research-based Innovation (the Research Council of Norway; grant no. 237841/030). We would like to thank Menno ter Veld for assistance in operating the experimental facility and also Ronald Booms and Tino Leffering for technical assistance during chemical analysis. Our thanks also go to Professor Trond Storebakken for helpful discussions.

\section{REFERENCES}

Austreng, E., Storebakken, T., Thomassen, M. S., Refstie, S., \& Thomassen, Y. (2000). Evaluation of selected trivalent metal oxides as inert markers used to estimate apparent digestibility in salmonids. Aquaculture, 188, 65-78.

Baeverford, G., \& Krogdahl, A. (1996). Development and regression of soybean meal induced enteritis in Atlantic salmon, Salmo salar L., distal intestine: A comparison with the intestines of fasted fish. Journal of Fish Diseases, 19, 375-387.

Beamish, F. W. H., \& Tandler, A. (1990). Ambient ammonia, diet and growth in lake trout. Aquatic Toxicology, 17, 155-166.

Bergot, F., \& Breque, J. (1983). Digestibility of starch by rainbow trout: Effects of the physical state of starch and of the intake level. Aquaculture, 34, 203-212.

Chikwati, E. M., Sahlmann, C., Holm, H., Penn, M. H., Krogdahl, Å., \& Bakke, A. M. (2013). Alterations in digestive enzyme activities during the development of diet-induced enteritis in Atlantic salmon, Salmo salar L. Aquaculture, 402-403, 28-37.

Dosdat, A., Ruyet, J. P.-L., Covès, D., Dutto, G., Gasset, E., Le Roux, A., \& Lemarié, G. (2003). Effect of chronic exposure to ammonia on growth, food utilisation and metabolism of the European sea bass (Dicentrarchus labrax). Aquatic Living Resources, 16, 509-520.

Ellis, T., North, B., Scott, A. P., Bromage, N. R., Porter, M., \& Gadd, D. (2002). The relationships between stocking density and welfare in farmed rainbow trout. Journal of Fish Biology, 61, 493-531.

Førde-Skjærvik, O., Refstie, S., Aslaksen, M., \& Skrede, A. (2006). Digestibility of diets containing different soyabean meals in Atlantic cod (Gadus morhua); comparison of collection methods and mapping of digestibility in different sections of the gastrointestinal tract. Aquaculture, 261, 241-258.

Francis, G., Makkar, H. P. S., \& Becker, K. (2001). Antinutritional factors present in plant-derived alternate fish feed ingredients and their effects in fish. Aquaculture, 199, 197-227.

Glencross, B. D. (2009). Reduced water oxygen levels affect maximal feed intake, but not protein or energy utilization efficiency of rainbow trout (Oncorhynchus mykiss). Aquaculture Nutrition, 15, 1-8.

Glencross, B., Rutherford, N., \& Bourne, N. (2012). The influence of various starch and non-starch polysaccharides on the digestibility of diets fed to rainbow trout (Oncorhynchus mykiss). Aquaculture, 356-357, 141-146.

Han, L. K., Xu, B. J., Kimura, Y., Zheng, Y. N., \& Okuda, H. (2000). Platycodi radix affects lipid metabolism in mice with high fat diet-induced obesity. Journal of Nutrition, 130, 2760-2764.

Hansen, J. Ø., \& Storebakken, T. (2007). Effects of dietary cellulose level on pellet quality and nutrient digestibilities in rainbow trout (Oncorhynchus mykiss). Aquaculture, 272, 458-465.

Holm, J., Björck, I., Ostrowska, S., Eliasson, A. C., Asp, N. G., Larsson, K., \& Lundquist, I. (1983). Digestibility of Amylose-Lipid Complexes in-vitro and in-vivo. Starch - Stärke, 35, 294-297.

Kolarevic, J., Selset, R., Felip, O., Good, C., Snekvik, K., Takle, H., ... Terjesen, B. F. (2013). Influence of long term ammonia exposure on Atlantic salmon (Salmo salar L.) parr growth and welfare. Aquaculture Research, 44, 1649-1664.

Kramer, D. L. (1987). Dissolved oxygen and fish behavior. Environmental Biology of Fishes, 18, 81-92.

Kraugerud, O. F., Penn, M., Storebakken, T., Refstie, S., Krogdahl, Å., \& Svihus, B. (2007). Nutrient digestibilities and gut function in Atlantic salmon (Salmo salar) fed diets with cellulose or non-starch polysaccharides from soy. Aquaculture, 273, 96-107.

Krogdahl, Å., Bakke-Mckellep, A., \& Baeverfjord, G. (2003). Effects of graded levels of standard soybean meal on intestinal structure, mucosal enzyme activities, and pancreatic response in Atlantic salmon (Salmo salar L.). Aquaculture Nutrition, 9, 361-371.

Krogdahl, Å., Sundby, A., \& Olli, J. J. (2004). Atlantic salmon (Salmo salar) and rainbow trout (Oncorhynchus mykiss) digest and metabolize nutrients differently. Effects of water salinity and dietary starch level. Aquaculture, 229, 335-360. 
Leenhouwers, J. I., Adjei-Boateng, D., Verreth, J. A. J., \& Schrama, J. W. (2006). Digesta viscosity, nutrient digestibility and organ weights in African catfish (Clarias gariepinus) fed diets supplemented with different levels of a soluble non-starch polysaccharide. Aquaculture Nutrition, 12, 111-116.

Lough, J. M., \& Hobday, A. J. (2011). Observed climate change in Australian marine and freshwater environments. Marine and Freshwater Research, 62, 984-999.

Meade, J. W. (1985). Allowable ammonia for fish culture. The Progressive Fish-Culturist, 47, 135-145.

Mosberian-Tanha, P., Øverland, M., Landsverk, T., Reveco, F. E., Schrama, J. W., Roem, A. J., ... Mydland, L. T. (2016). Bacterial translocation and in vivo assessment of intestinal barrier permeability in rainbow trout (Oncorhynchus mykiss) with and without soyabean meal-induced inflammation. Journal of Nutritional Science, 5, e26. (10 pages).

Nordrum, S., Krogdahl, Å., Røsjø, C., Olli, J. J., \& Holm, H. (2000). Effects of methionine, cysteine and medium chain triglycerides on nutrient digestibility, absorption of amino acids along the intestinal tract and nutrient retention in Atlantic salmon (Salmo salar L.) under pair-feeding regime. Aquaculture, 186, 341-360.

Oppedal, F., Dempster, T., \& Stien, L. H. (2011). Environmental drivers of Atlantic salmon behaviour in sea-cages: A review. Aquaculture, 311 $1-18$.

Opstvedt, J., Nygârd, E., Samuelsen, T. A., Venturini, G., Luzzana, U., \& Mundheim, H. (2003). Effect on protein digestibility of different processing conditions in the production of fish meal and fish feed. Journal of the Science of Food and Agriculture, 83, 775-782.

Ortega, V. A., Renner, K. J., \& Bernier, N. J. (2005). Appetite-suppressing effects of ammonia exposure in rainbow trout associated with regional and temporal activation of brain monoaminergic and CRF systems. Journal of Experimental Biology, 208, 1855-1866.

Øverland, M., Sørensen, M., Storebakken, T., Penn, M., Krogdahl, Å., \& Skrede, A. (2009). Pea protein concentrate substituting fish meal or soybean meal in diets for Atlantic salmon (Salmo salar)-Effect on growth performance, nutrient digestibility, carcass composition, gut health, and physical feed quality. Aquaculture, 288, 305-311.

Panserat, S. (2009). Molecular regulation of intermediary metabolism focusing on utilization of dietary carbohydrates. In K. Overturf (Ed.), Molecular research in aquaculture (pp. 261-278). Oxford, UK: Wiley-Blackwell.

Reeds, P. J., Wahle, K. W. J., \& Haggarty, P. (1982). Energy costs of protein and fatty acid synthesis. Proceedings of the Nutrition Society, 41, 155-159.

Refstie, S., Korsøen, Ø. J., Storebakken, T., Baeverfjord, G., Lein, I., \& Roem, A. J. (2000). Differing nutritional responses to dietary soybean meal in rainbow trout (Oncorhynchus mykiss) and Atlantic salmon (Salmo salar). Aquaculture, 190, 49-63.

Refstie, S., Landsverk, T., Bakke-Mckellep, A. M., Ringø, E., Sundby, A., Shearer, K. D., \& Krogdahl, Å. (2006). Digestive capacity, intestinal morphology, and microflora of 1-year and 2-year old Atlantic cod (Gadus morhua) fed standard or bioprocessed soybean meal. Aquaculture, 261, 269-284.

Refstie, S., Sahlström, S., Bråthen, E., Baeverfjord, G., \& Krogedal, P. (2005). Lactic acid fermentation eliminates indigestible carbohydrates and antinutritional factors in soybean meal for Atlantic salmon (Salmo salar). Aquaculture, 246, 331-345.

Refstie, S., Storebakken, T., \& Roem, A. (1998). Feed consumption and conversion in Atlantic salmon (Salmo salar) fed diets with fish meal, extracted soybean meal or soybean meal with reduced content of oligosaccharides, trypsin inhibitors, lectins and soya antigens. Aquaculture, 162, 301-312.

Romarheim, O. H., Hetland, D. L., Skrede, A., Øverland, M., Mydland, L. T., \& Landsverk, T. (2012). Prevention of soya-induced enteritis in Atlantic salmon (Salmo salar) by bacteria grown on natural gas is dose dependent and related to epithelial MHC II reactivity and CD $8 \alpha+$ intraepithelial lymphocytes. British Journal of Nutrition, 109, 1-9.
Romarheim, O. H., Skrede, A., Gao, Y., Krogdahl, Å., Denstadli, V., Lilleeng E., \& Storebakken, T. (2006). Comparison of white flakes and toasted soybean meal partly replacing fish meal as protein source in extruded feed for rainbow trout (Oncorhynchus mykiss). Aquaculture, 256, 354-364.

Romarheim, O. H., Skrede, A., Penn, M., Mydland, L. T., Krogdahl, A., \& Storebakken, T. (2008). Lipid digestibility, bile drainage and development of morphological intestinal changes in rainbow trout (Oncorhynchus mykiss) fed diets containing defatted soybean meal. Aquaculture, 274, 329-338.

Saravanan, S., Geurden, I., Figueiredo-Silva, A. C., Kaushik, S. J., Haidar, M. N., Verreth, J. A., \& Schrama, J. W. (2012). Control of voluntary feed intake in fish: A role for dietary oxygen demand in Nile tilapia (Oreochromis niloticus) fed diets with different macronutrient profiles. British Journal of Nutrition, 108, 1519-1529.

Storebakken, T., Kvien, I. S., Shearer, K. D., Grisdale-Helland, B., Helland, S. J., \& Berge, G. M. (1998). The apparent digestibility of diets containing fish meal, soybean meal or bacterial meal fed to Atlantic salmon (Salmo salar): Evaluation of different faecal collection methods. Aquaculture, 169, 195-210.

Sundh, H., Kvamme, B. O., Fridell, F., Olsen, R. E., Ellis, T., Taranger, G. L., \& Sundell, K. (2010). Intestinal barrier function of Atlantic salmon (Salmo salar L.) post smolts is reduced by common sea cage environments and suggested as a possible physiological welfare indicator. BMC Physiology, 10, 22.

Tran-Duy, A., Van Dam, A. A., \& Schrama, J. W. (2012). Feed intake, growth and metabolism of Nile tilapia (Oreochromis niloticus) in relation to dissolved oxygen concentration. Aquaculture Research, 43, 730-744.

Tran-Ngoc, K. T., Dinh, N. T., Nguyen, T. H., Roem, A. J., Schrama, J. W., \& Verreth, J. A. J. (2016). Interaction between dissolved oxygen concentration and diet composition on growth, digestibility and intestinal health of Nile tilapia (Oreochromis niloticus). Aquaculture, 462, 101-108.

Urán, P. A., Aydin, R., Schrama, J. W., Verreth, J. A. J., \& Rombout, J. H. W. M. (2008). Soybean meal-induced uptake block in Atlantic salmon, Salmo salar, distal enterocytes. Journal of Fish Biology, 73, 2571-2579.

Urán, P. A., Schrama, J. W., Rombout, J. H. W. M., Taverne-Thiele, J. J., Obach, A., Koppe, W., \& Verreth, J. A. J. (2009). Time-related changes of the intestinal morphology of Atlantic salmon, Salmo salar L., at two different soybean meal inclusion levels. Journal of Fish Diseases, 32, 733-744.

Vandenberg, G. W., \& De La Noüe, J. (2001). Apparent digestibility comparison in rainbow trout (Oncorhynchus mykiss) assessed using three methods of faeces collection and three digestibility markers. Aquaculture Nutrition, 7, 237-245.

Wu, R. S. S. (2002). Hypoxia: From molecular responses to ecosystem responses. Marine Pollution Bulletin, 45, 35-45.

\section{SUPPORTING INFORMATION}

Additional Supporting Information may be found online in the supporting information tab for this article.

How to cite this article: Mosberian-Tanha P, Schrama JW, Landsverk T, Mydland LT, and Øverland M. The effect of plant-based diet and suboptimal environmental conditions on digestive function and diet-induced enteropathy in rainbow trout (Oncorhynchus mykiss). Aquacult Nutr.

2018;24:112-122.https://doi.org/10.1111/anu.12539 